\title{
Cellulase Production by Co-culture of Bacillus licheniformis and B. paralicheniformis over Monocultures on Microcrystalline Cellulose and Chicken Manure-supplemented Rice Bran Media
}

\begin{abstract}
Muinat Olanike Kazeem, ${ }^{\mathrm{a}}$ Kamoldeen A. Ajijolakewu, ${ }^{\mathrm{a}}$ and Nor' Aini Abdul Rahman ${ }^{\mathrm{b}, *}$
Single cultures and co-cultures of Bacillus licheniformis and Bacillus paralicheniformis isolated from compost were evaluated for their carboxymethyl cellulase (CMCase) and filter paperase (FPase) production potential. Using a medium supplemented with microcrystalline cellulose (MCC), in the co-culture, CMCase and FPase activities increased 8.87and 2.28-fold and 10.15- and 3.20-fold over B. licheniformis and $B$. Paralicheniformis monocultures, respectively. The synergistic behavior of the two isolates might be due to the consumption of hydrolysis product (glucose, cellobiose) by one or both of the isolates, which improved their metabolic performance for cellulase secretion. Optimal conditions for cellulase production by this co-culture were a temperature of $45^{\circ} \mathrm{C}$, and $\mathrm{pH} 7$ at $180 \mathrm{rpm}$ in a medium containing rice bran at $1 \%(\mathrm{w} / \mathrm{v})$ and chicken manure as nitrogen supplement at $2 \%(\mathrm{w} / \mathrm{v})$. The maximum CMCase and FPase produced under the above conditions were $79.8 \mathrm{U} / \mathrm{mL}$ and 12.5 $\mathrm{U} / \mathrm{mL}$, respectively. This corresponds to $257.4-$ and 59.5 -fold enhancement in CMCase and FPase activity, respectively, over $B$. licheniformis monoculture, and 306.9- and 83.3-fold increase with respect to the $B$. paralicheniformis monoculture. These results indicate that improved cellulase production can be achieved through co-culture and chicken manure nitrogen-supplement.
\end{abstract}

Keywords: Cellulase; Bacillus licheniformis; Bacillus paralicheniformis; Co-culture; Monoculture; Microcrystalline cellulose; Rice bran; Chicken manure

Contact information: a: Department of Microbiology, Faculty of Life Sciences, University of Ilorin, 1515, Ilorin, Kwara State, Nigeria; b: Department of Bioprocess Technology, Faculty of Biotechnology and Biomolecular Sciences, Universiti Putra Malaysia, 43400 Serdang, Selangor, Malaysia;

*Corresponding author: nor'aini@upm.edu.my

\section{INTRODUCTION}

Lignocellulose is the most abundant renewable biomass in nature. It is synthesized by plants and can provide energy and renewable chemicals in biomanufacturing to create a sustainable bioeconomy. Lignocellulose is a complex structure consisting of cellulose, together with hemicellulose wound around by lignin. The biomass processing for the production of bioethanol from lignocellulose requires fermentable sugars as substrate produced through hydrolysis. Hence, fermentable sugars are either produced through chemical pretreatment or via enzymatic hydrolysis. Enzymatic hydrolysis is of particular research interest because it allows for the use of non-food plant materials, such as agrowaste products. It is also ecofriendly and readily secreted by microorganisms, hence contributing to building a sustainable bioeconomy. Due to heterogeneity of the lignocellulose biomass, enzymatic hydrolysis requires a complex system of enzymes, such 
as endoglucanase (endo-1,4-b-D-glucanase), exo-glucanase (1,4-b-D-glucan-cellobiohydrolase), $\beta$-glucosidase (b-D-glucoside glucanohydrolase, cellobiase), and other accessory enzymes, that work synergistically towards degradation of lignocellulose polysaccharides. However, the high cost of cellulase presents a major drawback to commercialization of lignocellulosic biorefinery. Therefore, an efficient, cost-effective cellulase production system with high enzyme titre is required to reduce the cost of bioethanol and other bioproducts produced from lignocellulose.

Most studies have focused on the use of monocultures for the production of cellulase rather than co-cultures. Microbial co-cultures present numerous advantages such as reduced capital investment, high productivity, synergistic behavior, reduction of metabolic burden, and rapid substrate utilization. Among co-cultures are those that help in stabilization of biomass (Kato et al. 2005) and enhancement of product recovery through distribution of metabolic pathways (Zhou et al. 2015). Likewise, co-cultures are more robust to environmental stress (Balachandar et al. 2013) and are therefore more likely to withstand the changes in $\mathrm{pH}$, temperature, and metal ions, as experienced with industrial fermentations. Hence, they are good candidates for industrial bioprocessing of cellulosic biomass. Pectinase production was reported to be enhanced by co-culture of Bacillus subtilis and B. pumilus by 2-fold compared to the monocultures during growth on apple pomace carbon source (Kuvvet et al. 2019). A co-culture of Trichoderma asperellum and Bacillus amyloliquefaciens produced the best composition of lignocellulosic enzymes and the highest biomass hydrolysis yield (Karuppiah et al. 2021). The cellulase activity of mixed culture of Aspergillus niger and Trichoderma reesei increased 2.238-fold in comparison to the monocultures (Septiani et al. 2019). Similarly, Zhao et al. (2018) examined cellulase production using co-cultures of $A$. niger and $T$. reesei and reported increased degradation capacity of steam exploded corn stover.

Although numerous bacteria and fungi have been applied for the production of biocatalysts, members of the firmicutes have been mostly reported and are versatile in the biodegradation of lignocellulosic biomass from various environments (Ransom-Jones et al. 2017). The utilization of bacteria for cellulase production offers enormous advantages: (i) ability to inhabit diverse environments, (ii) rapid growth rate, (iii) efficient enzyme complexes, and (iv) genetic amenability. Hence, the single strain bacteria inoculation has been commonly employed for cellulase production. However, this strategy is contrary to what is obtained in the natural environment where degradation of biomass is facilitated by consortia of microbes. These consortia can thus be explored for efficient production of biocatalysts. A well-defined bacterial consortium may contribute significantly towards improving cellulase production. Furthermore, application of bacterial consortia could further shed light on the role of the individual strains, as well as their mechanisms and metabolic pathways for biomass degradation. Therefore, the use of bacterial co-cultures can advance cellulase production by helping to unravel the complex and multifaceted interactions that occur during the biodegradation of lignocellulose.

Strains of $B$. licheniformis have been investigated for cellulase production on different cellulosic materials such as wheat bran (Gupta et al. 2015), sugarcane bagasse (Afzal et al. 2019), and sugarcane bagasse + rice husk (Kazeem et al. 2016). However, data are not available regarding the use of $B$. paralicheniformis for cellulase production. However, the use of consortium of these bacteria for cellulase production has not been reported, particularly on agro-wastes, such as rice bran, rice straw, cow dung, and their mixtures, supplemented with chicken manure. 
Rice bran is a by-product from the rice milling industry while rice straw is the byproduct from rice harvest. Cow dung is the dry excreta from cows. It is abundant and underexploited with respect to cellulase production. It contains $35.4 \%$ cellulose, $32.6 \%$ hemicelluloses, and 1.4\% nitrogen (Misra et al. 2003). It has several essential nutrients, such as $\mathrm{Ca}, \mathrm{Mg}, \mathrm{S}, \mathrm{Zn}, \mathrm{B}, \mathrm{Cu}$, and Mn (Onwudike 2010). Thus, these products present a promising feed stock for cellulase production.

In addition, the use of crop and animal wastes is an opportunity to improve the bioeconomy through the adoption of a zero-waste farming system. Rice straw consists of 35 to $40 \%$ cellulose, 25 to $30 \%$ hemicellulose, and 10 to $15 \%$ lignin (Rahnama et al. 2013). Rice bran consists of $15 \%$ cellulose, $31 \%$ hemicellulose, and $11 \%$ lignin (Sunphorka et al. 2012), while cow dung is composed of $26 \%$ cellulose, $11 \%$ hemicellulose, and $11 \%$ lignin (Zulkifli et al. 2018). Chicken manure is a good source of nitrogen, as it has been used as nitrogen source for co-composting of rice straw (Karanja et al. 2019). Similarly, composting of chicken manure and organic waste improved the compost quality (Hwang et al. 2020). Therefore, these materials are rich in nutrients and carbohydrates that can support the growth of bacteria for use in cellulase production.

In this context the aim of the current work is to demonstrate the efficacy of coculture of $B$. licheniformis and $B$. paralicheniformis grown of agro-waste biomass supplemented with chicken manure under optimal conditions for the production of low cost cellulase.

\section{EXPERIMENTAL}

\section{Materials}

Microorganisms and their preparation

The bacterial strains 2B40 and 20B40 later identified in this study as Bacillus licheniformis and Bacillus paralicheniformis were obtained from the Biomass Laboratory, Biotech 3, Department of Bioprocess Technology, Universiti Putra Malaysia. They were isolated from the composting of oil palm empty fruit bunch and chicken manure. A portion of the cultures from Luria bertani (LB) broth-glycerol freeze stock was collected and transferred into $10 \mathrm{~mL} \mathrm{LB}$ broth and incubated for $45^{\circ} \mathrm{C}$ at $180 \mathrm{rpm}$ for $24 \mathrm{~h}$. The cultures were streaked on nutrient agar plate and carboxymethyl cellulose (CMC)-Congo red agar plates to ensure purity and confirmation of cellulolytic capacity. The isolates produced hydrolytic capacity of $2.4 \pm 0.2$ on CMC-Congo red agar plate.

\section{Agro-waste biomass and chicken manure substrate preparation and pretreatment}

Rice straw was collected from a rice farm at the Faculty of Agriculture, University Putra Malaysia, while the rice husk and rice bran were obtained from Bernass Bhd rice processing factory, Sekinchan, Selangor, Malaysia. The chicken manure was collected from the Faculty of Agriculture poultry farm, Universiti Putra Malaysia. The rice straw and rice husk were washed thoroughly in several changes of distilled water to remove extraneous materials. They were then dried at $60{ }^{\circ} \mathrm{C}$ for $24 \mathrm{~h}$ and ground to $0.25 \mathrm{~mm}$ particle size using a grinding machine (Retsch SM 200, Rostfrei, Hann, Germany). The rice straw and rice husk were pretreated in $2 \%(\mathrm{w} / \mathrm{v}) \mathrm{NaOH}$ for $2 \mathrm{~h}$ at 1:10 solid-liquid loading and then autoclaved at $121{ }^{\circ} \mathrm{C}$ for $10 \mathrm{~min}$. The pretreated solid was extracted and washed in several changes of distilled water until neutral $\mathrm{pH}$ and was oven-dried at $60{ }^{\circ} \mathrm{C}$. The chicken manure and dried cow dung was milled with a kitchen blender and sieved to 
powder. All the substrates were stored in air-tight polyethylene plastic bags at $4{ }^{\circ} \mathrm{C}$ until further use.

\section{Methods}

Inoculum preparation

The bacteria strains were cultured up to their log phase of $24 \mathrm{~h}$ on cellulase medium containing (g/L): 0.1 carboxymethylcellulose (CMC), $1.0 \mathrm{KH}_{2} \mathrm{PO}_{4}, 1.145 \mathrm{~K}_{2} \mathrm{HPO}_{4}, 0.4$ $\mathrm{MgSO}_{4} \cdot 7 \mathrm{H}_{2} \mathrm{O}, 5.0 \mathrm{NH}_{4} \mathrm{SO}_{4}, 0.05 \mathrm{CaCl}_{2} \cdot 2 \mathrm{H}_{2} \mathrm{O}$, and $1 \mathrm{~mL}$ Nitsch's trace element solution (2.2 $\mathrm{g} \mathrm{MnSO}_{4}, 0.5 \mathrm{~g} \mathrm{ZnSO}_{4}, 0.5 \mathrm{~g} \mathrm{H}_{3} \mathrm{BO}_{3}, 0.016 \mathrm{~g} \mathrm{CuSO}_{4}, 0.025 \mathrm{~g} \mathrm{Na}_{2} \mathrm{MoO}_{4}$, and $0.046 \mathrm{~g}$ $\mathrm{CoCl}_{2}$ ) (Rastogi et al. 2009). From this, $50 \mathrm{~mL}$ of the culture was centrifuged at 10,000 $\times$ $\mathrm{g}$ and $4{ }^{\circ} \mathrm{C}$ for $10 \mathrm{~min}$. The cell pellet was subjected to repeated washing and resuspended in $0.1 \%$ (w/v) peptone (King and Hurst 1963). The cell suspension was set at optical density $\left(\mathrm{OD}_{600}\right) \mathrm{OD}_{600}=1.0$ and used as inoculum for cellulase production.

\section{Characterization of the cellulolytic bacteria using cultural and BIOLOG method}

The morphological characteristics such as colour, margin, and surface were done by physical examination on a $24 \mathrm{~h}$ old Luria Bertani (LB) agar plate. The gram reaction, spore staining, and motility were viewed under the microscope following standard laboratory procedures. Both isolates were grown in aerobic and anaerobic incubators to test their respiration requirement. The physiological properties were carried out in $50 \mathrm{~mL} \mathrm{LB}$ broth prepared according to the manufacturer's instruction. As for salt tolerance, the isolates were grown in $\mathrm{LB}$ broth containing 1 to $8 \% \mathrm{NaCl}$ concentration, then incubated at $40{ }^{\circ} \mathrm{C}$ for $24 \mathrm{~h}$. The temperature preference $\left(40\right.$ to $60^{\circ} \mathrm{C}$ ) was carried out following the same procedure without the addition of $\mathrm{NaCl}$. The $\mathrm{pH}$ of the $\mathrm{LB}$ broth was adjusted to 5, 7 and 9 before incubation at $40^{\circ} \mathrm{C}$ for $24 \mathrm{~h}$. For all the physiological properties, the isolates were set at optical density (OD) 0.6 before inoculating into the LB broth at $1 \%$. The initial OD (before incubation) and final OD (after $24 \mathrm{~h}$ incubation) were examined for positive growth or negative growth.

Following the manufacturer's instruction, a 16-h bacteria suspension obtained from a Nutrient agar plate was transferred into an inoculating fluid (IF-A) to attain 95\% transmittance cell density using a Biolog turbidimeter (Biolog Inc. Hayward, CA, USA). An inoculum of $100 \mu \mathrm{L}$ was transferred into wells on the GENIII microplate and incubated at $33{ }^{\circ} \mathrm{C}$ between 16 to $24 \mathrm{~h}$. A colour change of the teterazolium dye to purple was recorded on the microplate plate reader. The results obtained were compared with the information on the BIOLOG database software (Biolog Inc. 5160-WX, Hayward, CA, USA).

$16 S$ rDNA gene sequencing and phylogenetic analysis

Genejet genomic DNA extraction and purification kit was used for genomic DNA extraction (Thermo Scientific Inc., Waltham, MA, USA). The extracted DNA was used for the polymerase chain reaction to amplify a portion of the $16 \mathrm{~S}$ rDNA using a universal primer 27F (5'-AGA GTT TGA TCC TGG CTC AG-3') and 1492R (5'-GGT TAC CTT GTT ACG ACT T-3'), on a T-gradient thermocycler (LabRepCo, Horsham, PA, USA). The PCR reaction mixture consisted of $12.5 \mu \mathrm{L}$ REDTaq, PCR Reaction Mix (SigmaAldrich, St. Louis, MO, USA), $1 \mu \mathrm{L}$ each of forward and reverse primers and $35.5 \mu \mathrm{L}$ of sterile distilled water. The following PCR conditions were used for the amplification: 98 ${ }^{\circ} \mathrm{C}$ for $5 \mathrm{~min}$ for an initial denaturation step, followed by 35 cycles of $95{ }^{\circ} \mathrm{C}$ for $30 \mathrm{~s} ; 45.3$ ${ }^{\circ} \mathrm{C}$ for $30 \mathrm{~s} ; 72{ }^{\circ} \mathrm{C}$ for $90 \mathrm{~s}$ denaturation annealing and extension, and final extension at 72 
${ }^{\circ} \mathrm{C}$ for $8 \mathrm{~min}$. The amplified PCR products were purified and sent to $1^{\text {st }}$ BASE (Selangor, Malaysia) for sequencing. The sequence similarities were compared with the ones available in the NCBI Gene Bank data. The MEGA version 6.0 was used to construct a phylogenetic tree, using the neighbor-joining method (Tamura et al. 2013).

\section{Cellulase production by mono and co-culture of cellulolytic bacteria}

Production of cellulase was carried out in $50 \mathrm{~mL}$ cellulase medium in 100-mL conical flask containing $1 \%$ microcrystalline cellulose (MCC). The content was sterilized at $121{ }^{\circ} \mathrm{C}$ for $15 \mathrm{~min}$ prior to inoculation of the bacteria cells. A $5 \%$ inoculum of each bacterial strain was inoculated into separate fermentation flasks and incubated at $50{ }^{\circ} \mathrm{C}$ for $48 \mathrm{~h}$ at $180 \mathrm{rpm}$ for the monocultures. For the co-culture, an inoculum load of $2.5 \%$ of each bacterial culture was used. A $2 \mathrm{~mL}$ sample was collected at $6 \mathrm{~h}$ interval and centrifuged at $10,000 \times \mathrm{g}$ for $20 \mathrm{~min}$ at $4{ }^{\circ} \mathrm{C}$ (Sorvall RC-2B, Thermo Scientific, Waltham, MA, USA). The supernatant was withdrawn and used as crude enzyme for analysis of the various enzyme activities.

\section{Optimization of enzyme production}

To select a suitable temperature and $\mathrm{pH}$ for the production of cellulase by co-culture of $B$. licheniformis and $B$. paralicheniformis, the isolates were cultivated at a temperature range of 40 to $60{ }^{\circ} \mathrm{C}$ and $\mathrm{pH} 3$ to 8 . The effect of nutritional parameters on cellulase production by the co-culture were assessed on carbon sources (single and mixed agrowaste) and nitrogen sources (organic and inorganic nitrogen). For the carbon sources, the shake flask was inoculated with $1 \%$ of either rice bran (RB), rice straw (RS), cow dung $(C D)$, rice bran + rice straw $(R B+R S)$, rice bran + cow dung $(R B+C D)$, rice straw + cow dung $(\mathrm{RS}+\mathrm{CD})$, or rice bran + rice straw + cow dung $(\mathrm{RB}+\mathrm{RS}+\mathrm{CD})$. The nitrogen sources were tested at different concentrations of chicken manure (CM). These included CM1, $\mathrm{CM} 2, \mathrm{CM} 3, \mathrm{CM} 4$, and CM5 corresponding to 1 to $5 \%$ chicken manure, respectively. The effect of chicken manure concentration was compared with $\mathrm{NH}_{4} \mathrm{SO}_{4}$ and peptone at $5 \mathrm{~g} / \mathrm{L}$.

\section{Analytical Methods}

Enzyme assay

The activity of crude enzyme was determined using the method described by Wood and Bhat (1988). Carboxymethyl cellulase (CMCase) activity was determined by measuring the reducing sugar released from CMC. A volume of $0.5 \mathrm{~mL}$ crude enzyme was reacted with $0.5 \mathrm{~mL}$ of $1 \% \mathrm{CMC}$ in $0.05 \mathrm{M}$ phosphate buffer $(\mathrm{pH} 7)$ and incubated at 50 ${ }^{\circ} \mathrm{C}$ for $30 \mathrm{~min}$. Filter paperase (FPase) was determined by measuring sugar released from filter paper. In this reaction, $0.5 \mathrm{~mL}$ crude enzyme was mixed with $1 \times 6 \mathrm{~cm}$ Whatman No. 1 filter paper immersed in $1.5 \mathrm{~mL}$ of phosphate buffer $(\mathrm{pH} 7)$ and incubated at $50{ }^{\circ} \mathrm{C}$ for 1 h. Reducing sugar was measured using the DNS method (Miller 1959). The reaction was stopped with the addition of $3 \mathrm{~mL} \mathrm{3,5-dinitrosalicylic} \mathrm{acid} \mathrm{(DNS).} \mathrm{One} \mathrm{unit} \mathrm{of} \mathrm{enzyme}$ activity is determined as the amount of enzyme required to liberate $1 \mu \mathrm{mol}$ of reducing sugar/min under the assay conditions (Wood and Bhat 1988)

\section{Statistical analysis}

The values shown are the means of triplicates \pm standard deviation. Data were analyzed by one way analysis of variance (ANOVA). Duncan's multiple range was used 
to compare the means among treatment groups. Differences of $P<0.05$ were considered significant using SAS software package version 9.4 (SAS Institute Inc., Cary, NC, USA).

\section{RESULTS AND DISCUSSION}

\section{Characterization and Identification of the Bacteria Isolates}

Morphological and physiological identification of the isolates is as shown in Table 1 , while the biochemical characterization was determined following the BIOLOG GENIII method (Table 2). The morphological examination of isolates shows that they are Gram positive rod, motile, spore forming aerobic bacteria with serrated margins. Isolate 2B40 was whitish in colour while isolate 20B40 appeared creamy-white. The isolates established the ability to grow on $\mathrm{CMC}$-agar, $\mathrm{NaCl}$ concentration 1 to $8 \%$, at a temperature range of 40 to $60{ }^{\circ} \mathrm{C}$ and within $\mathrm{pH} 5$ to 9 except isolate 20B40, which showed no growth at pH 5. Based on carbon source utilization, the isolates likely make use of some carbon 5 and carbon 6 sugars, some of which are Dextrin, D-Maltose, D-Trehalose, D-Cellobiose, Gentobiose, Sucrose, D-Turanose, D-Glucose, D-Mannose, D-Sorbitol, and D-Mannitol. They also demonstrate tolerance towards acids such as: L-Lactic acid, L-Mallic acid, DGluconic acid, D-Galactouronic acid, L-Arginine, and L-Aspertic acid, except for Propionic acid and Formic acid.

Table 1. Morphological and Physiological Characterization of Cellulolytic Isolates

\begin{tabular}{|c|c|c|}
\hline Parameter & \multicolumn{2}{|c|}{ Cellulolytic Isolates } \\
\hline Morphological Characterization & $2 \mathrm{~B} 40$ & $20 \mathrm{~B} 40$ \\
\hline Shape & Rod & Rod \\
\hline Colour & Whitish & Creamy-white \\
\hline Gram reaction & + & + \\
\hline Motility & + & + \\
\hline Spore & + & + \\
\hline Margin & Serrated & Serrated \\
\hline Surface & + & Rough \\
\hline Aerobic & - & + \\
\hline Anaerobic & & - \\
\hline Physiological Properties & + & + \\
\hline Growth on CMC agar & + & + \\
\hline $1 \% \mathrm{NaCl}$ & + & + \\
\hline $4 \% \mathrm{NaCl}$ & + & + \\
\hline $8 \% \mathrm{NaCl}$ & + & + \\
\hline $40^{\circ} \mathrm{C}$ & + & + \\
\hline $50{ }^{\circ} \mathrm{C}$ & - & + \\
\hline $60^{\circ} \mathrm{C}$ & + & + \\
\hline $\mathrm{pH} 5$ & + & + \\
\hline $\mathrm{pH} 7$ & + & \\
\hline $\mathrm{pH} 9$ & & + \\
\hline
\end{tabular}

$+=$ Positive, $-=$ Negative 
Additionally, both isolates display sensitivity to vancomycin, rifampicin, and nalidixic acid and could metabolize salt of lithium, potassium, and sodium. Biochemical characterization of bacteria isolates using BIOLOG provides an insight into the metabolic properties of the isolates, and it has been reported to characterize some bacteria isolates such as B. licheniformis 2D55 (Kazeem et al. 2017) and Streptomyces sp. (Samad et al. 2020).

Table 2. Biochemical Characterization of Cellulolytic Isolate using BIOLOG GEN

\begin{tabular}{|c|c|c|c|c|c|}
\hline Carbon Utilization & 2B40 & 20B40 & $\begin{array}{c}\text { Acid and Salt } \\
\text { Utilization/ Antibiotic } \\
\text { Sensitivity }\end{array}$ & 2B40 & 20B40 \\
\hline Dextrin & + & nd & Acid & & \\
\hline D-Maltose & + & + & L-Glutamic acid & + & nd \\
\hline D-Trehalose & - & + & D-Galactouronic acid & + & + \\
\hline D-Cellobiose & + & + & D-Gluconic acid & + & + \\
\hline Gentiobiose & + & + & Mucic acid & + & + \\
\hline Sucrose & + & + & L-Lactic acid & + & + \\
\hline D-Turanose & + & + & L- Citric acid & + & nd \\
\hline D-Raffinose & + & nd & Propionic acid & nd & nd \\
\hline$\alpha$-D-Lactose & nd & - & L-Mallic acid & + & + \\
\hline D-Mellibiose & + & nd & L-Alanine & + & nd \\
\hline$\alpha$-D-Glucose & + & + & L-Arginine & + & + \\
\hline D-Mannose & + & + & L-Aspertic acid & + & + \\
\hline D-Fructose & + & + & Formic acid & nd & nd \\
\hline D-Galactose & nd & nd & Antibiotics & & \\
\hline L-Rhamnose & + & - & Vancomycin & - & - \\
\hline D-Sorbitol & + & + & Rifamycin & - & - \\
\hline D-Mannitol & + & + & Nalidixic acid & - & - \\
\hline D-Arabitol & nd & - & Salt & + & + \\
\hline Glycerol & + & + & Lithium chloride & + & + \\
\hline Gelatin & + & nd & Sodium lactate & + & + \\
\hline Pectin & + & + & Pottasium tellurite & + & + \\
\hline Stachyose & + & + & Sodium butyrate & & \\
\hline
\end{tabular}

$+=$ Positive,$-=$ Negative, $n d=$ undetermined

\section{Identification of isolate $2 B 40$ and $20 B 40$ using $16 S$ rDNA}

The nucleotide sequence of the PCR products obtained from isolate $2 \mathrm{~B} 40$ and 20B40 was compared with other sequences from the 16S rDNA in the Gene Bank Data base using BLAST N (Fig. 1). The phylogenetic tree generated using the neighbor joining method showed relatedness with species of Bacillus and Geobacillus. Isolate 2B40 showed 99\% similarity with Bacillus licheniformis KP081r, while isolate $20 \mathrm{~B} 40$ presented 99\% similarity with Bacillus paralicheniformis PB61. Species of Bacillus species have been isolated and reported to play a major role in agro-waste degradation during composting (Bhattacharya and Pletschke 2014; Kinet et al. 2015). Amore et al. (2013), also reported the isolation of novel cellulolytic bacteria most of which belong to the members of genera Bacillus. 


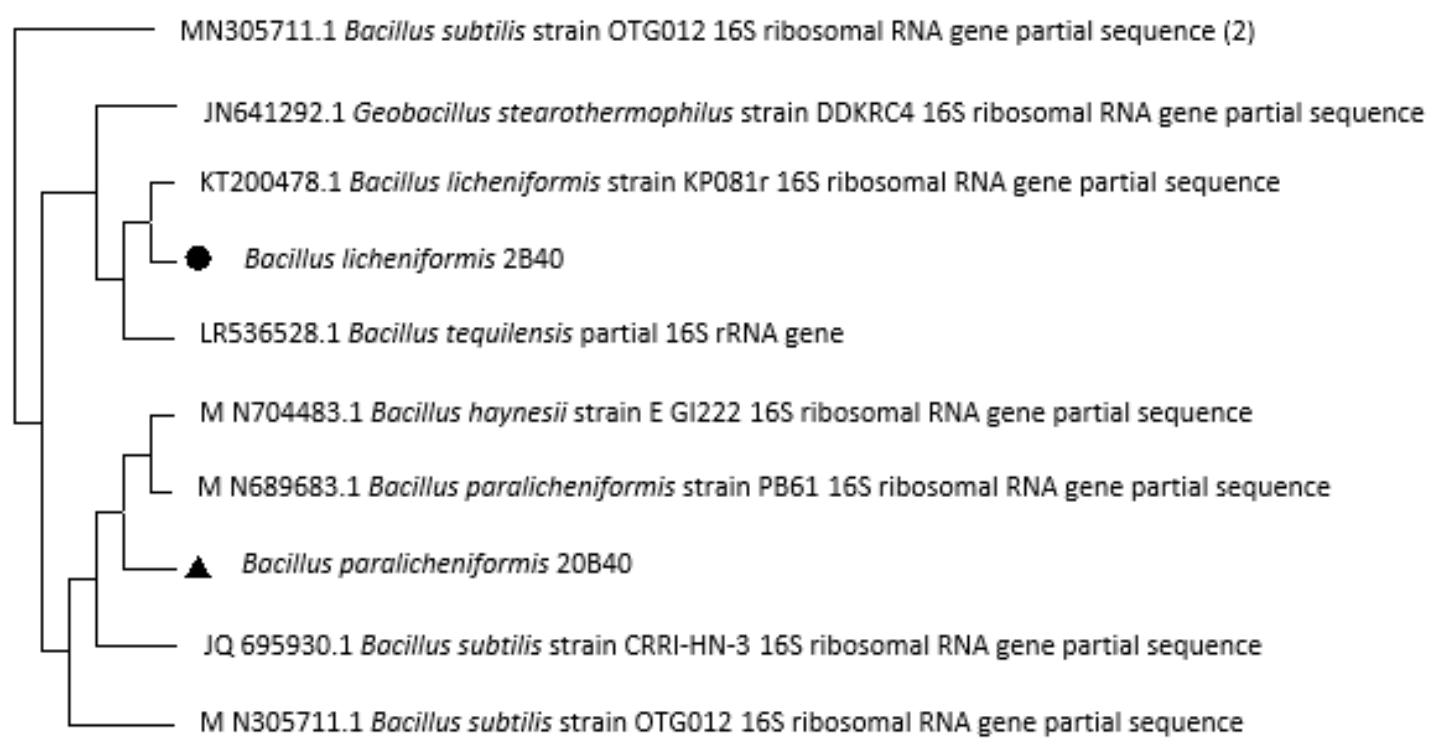

Fig. 1. Phylogenetic dendrogram showing relatedness of $16 \mathrm{~S}$ rDNA of isolate $2 B 40$ and $20 B 40$ with related bacteria strains from gene data bank using the neighbor joining method

CMCase and FPase production by B. licheniformis $2 B 40$ and B. paralicheniformis $20 B 40$ monocultures

The production of CMCase and FPase on microcrystalline cellulose by monocultures of B. licheniformis 2B40 and B. paralicheniformis 20B40 was monitored for $48 \mathrm{~h}$. The results presented in Figs. 2 and 3 show the CMCase and FPase production profiles of B. licheniformis 2B40 B. paralicheniformis 20B40, respectively. It was observed that the CMCase and FPase activities increased with time up to maximum titre at $30 \mathrm{~h}$, after which the activities progressively declined until $48 \mathrm{~h}$. The result is in contrast with the report of Rastogi et al. (2010), where optimal CMCase and cellulase activities were attained on different fermentation days. Because cellulases work synergistically for efficient hydrolysis of lignocellulose, obtaining maximum yield of the component enzymes at the same fermentation period supports maximum activity, yield, and productivity. Hence, this shows compatibility of both isolates with regards to extracting maximal cellulase titer.

Researchers have reported cellulase production by Bacillus sp. in previous studies (Ariffin et al. 2008; Liang et al. 2014; Salim et al. 2017). However, most of them utilized CMC or agro-waste biomass while focusing only on CMCase production. Therefore, little comparison could be made with the results from this study in that regard. Nonetheless, Rastogi et al. (2010) have shown that maximum CMCase $(0.12 \mathrm{U} / \mathrm{mL})$ was detected when the Bacillus sp. DUSELR 13 was grown on microcrystalline at $60{ }^{\circ} \mathrm{C}$ on day 9 while maximum cellulase $(0.03 \mathrm{U} / \mathrm{mL})$ was attained on day 8 . The result from these researchers was lower than that obtained in the current study where CMCase and FPase produced by B. licheniformis reached optimum at $0.31 \mathrm{U} / \mathrm{mL}$ and $0.21 \mathrm{U} / \mathrm{mL}$, respectively, at $48 \mathrm{~h}$. Although Kazeem et al. (2017) reported optimal cellulase production by fast-growing $B$. licheniformis 2D55 at $18 \mathrm{~h}$ on microcrystalline cellulose, the FPase activity (CMCase 0.33 $\mathrm{U} / \mathrm{mL}$ and FPase $0.09 \mathrm{U} / \mathrm{mL}$ ) was much lower than that obtained in the current study. $B$. paralicheniformis produced maximum CMCase and FPase at 0.28 and $0.15 \mathrm{U} / \mathrm{mL}$, respectively. As far as the authors know, this is the first report on cellulase production by 
B. paralicheniformis 20B40 on microcrystalline cellulose. Comparison with other strains of $B$. paralicheniformis was not possible, as data on cellulase production by this organism is limited. It was noteworthy that both isolates produced higher CMCase activity than FPase activity. In the study of cellulases, CMC, an amorphous cellulose is used to study CMCase (endoglucanase), while MCC, an example of crystalline cellulose is used to study FPase (exoglucanase). In the current study both isolates produced higher CMCase than FPase even when MCC was used as the only carbon source. Therefore, it could be inferred that the cellulase secreted by both isolates is an endoglucanase with lesser exoglucanase activities.

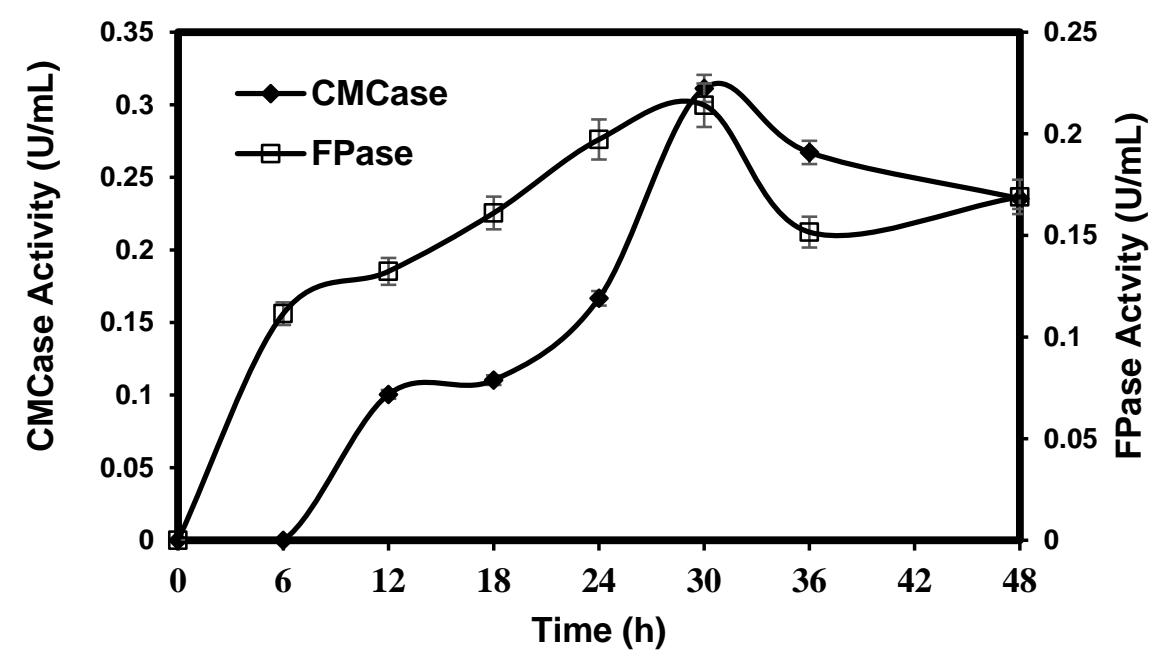

Fig. 2. CMCase and FPase production profile of isolate 2B40 (B. licheniformis) during growth on MCC medium. Values are means of $(n=3), \pm$ SD. Mean are significant at $(p<0.05)$ Enzyme activity was carried out at $\mathrm{pH} 7$ and $50^{\circ} \mathrm{C}$.

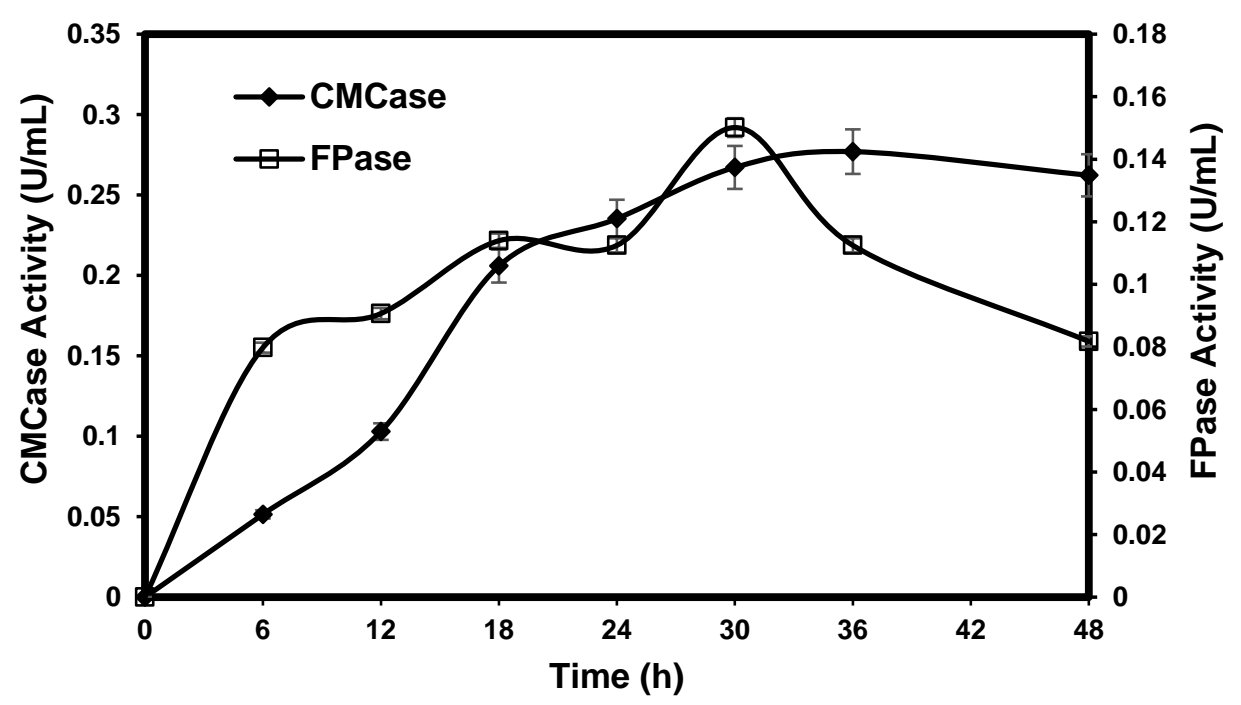

Fig. 3. CMCase and FPase production profile of isolate 20B40 (B. paralicheniformis) grown on MCC medium. Values are means of $(n=3), \pm$ SD. Mean are significant at $(p<0.05)$ Enzyme activity was carried out at $\mathrm{pH} 7$ and $50^{\circ} \mathrm{C}$. 
Lower CMCase activity compared to FPase on the same inducer substrate is a common occurrence in numerous studies. This is because CMC is an amorphous form of cellulose that is easier to digest than filter paper (Oni et al. 2020). Because some enzymes are cell bound, the analysis of cellulase from cell-free extract alone might underestimate the cellulase production by the isolate. Slow growth is one of the problems associated with fermentation by thermophilic microorganisms. Therefore, efforts aimed at faster growth rate for improving cellulase titre could be achieved through the use of co-cultures as done in this study. Aside from this, culture optimization and medium compositions could enhance cellulase production from thermophilic organisms.

\section{CMCase and FPase production from co-culture}

It has been earlier identified that low production of cellulase from biomass using bacteria mono-culture is a principal factor affecting the high cost of enzyme. Hence, to maximize the production of cellulase, mono and co-culture fermentation of $B$. licheniformis 2B40 and B. paralicheniformis 20B40 was performed. The CMCase and FPase production was monitored on growth medium containing MCC as carbon source using co-culture of the two bacterial species (Fig. 4) and was compared with the production by the monoculture. It was observed that the co-culture of B. licheniformis and B. paralicheniformis improved the CMCase and FPase production over the mono-culture cultivation. The CMCase and FPase activity was improved to 2.75 and $0.48 \mathrm{U} / \mathrm{mL}$, respectively. One noteworthy observation from this result was that the CMCase and FPase activities produced by the co-culture increased up to 8.87- and 2.29-fold, respectively, over that of $B$. licheniformis, and 10.19- and 3.20-fold over the B. paralicheniformis mono-culture. It was also confirmed that the lower FPase activity experienced with $B$. paralicheniformis was boosted by co-culturing with $B$. licheniformis. This result was possibly due to compatibility and synergistic behavior of the two strains, resulting in reduced chances of contamination, co-utilization of biomass, and relief from metabolic stress.

The strategy of using co-culture could reduce the cost of cellulase production, which is predominantly based on single culture. Many studies have reported increased enzyme production on co-cultures over single cultures. Recently, Yang et al. (2021) reported a $30 \%$ to $70 \%$ increase in cellulase activity after co-culturing Bacillus licheniformis A5 and Bacillus subtilis B2. Similarly, co-culturing the two strains increased degradation rate of Chinese distillers grains by $70 \%$ compared with optimized results of Bacillus subtilis B2 mono-culture. A study conducted by Dabhi et al. (2014) reported the highest CMCase $1.716 \mathrm{U} / \mathrm{mL}$ and FPase $0.178 \mathrm{U} / \mathrm{mL}$ from the bacteria isolates used as consortia. Meanwhile, $0.5 \mathrm{U} / \mathrm{mL}$ and $0.138 \mathrm{U} / \mathrm{mL}$ CMCase and FPase, respectively, were obtained from the mono-culture of $B$. megaterium. In another study, the production of endoglucanase and exoglucanase activity at $0.014 \mathrm{U} / \mathrm{mL}$ and $0.041 \mathrm{U} / \mathrm{mL}$, respectively, were observed in culture consortium (Park et al. 2012). The study conducted by Singh et al. (2019) reported CMCase activity at $0.21 \mathrm{U} / \mathrm{mL}$ and FPase activity at $0.30 \mathrm{U} / \mathrm{mL}$ for enzyme production by consortium (B. subtilis BHUJPV-H19, B. stratosphericus BHUJPV$\mathrm{H} 5$, and B. subtilis BHUJPV- H12), which was lower than what is reported in the current study. However, this study was in contrast to Rastogi et al. (2010) who observed that the co-culture of thermophilic Bacillus sp. DUCELR13 and Geobacillus sp. WSUCF1 did not result in any significant increase in cellulase production as compared to the mono-culture. Likewise, CMCase activity did not show higher enzyme activity in the consortia than the single bacteria strains (Singh et al. 2019). It could be inferred that the compatibility of individual bacteria strains is crucial to improvement in enzyme production by the co- 
cultures. It was noteworthy that the co-cultures used in the current study shows fantastic compatibility as expressed by the high enzyme production.

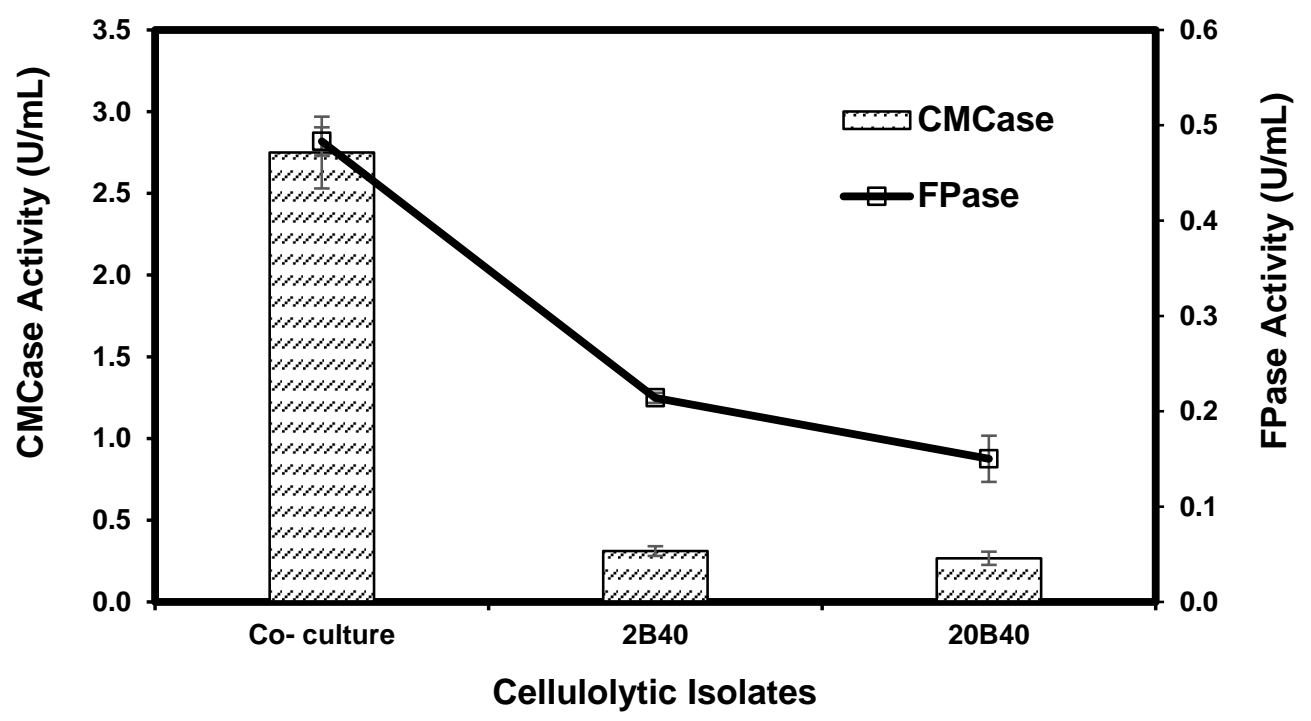

Fig. 4. Effect of monoculture and co-culture of isolate 2B40 (B. licheniformis) and 20B40 ( $B$. paralicheniformis) on CMCase and FPase activity production on MCC medium. Values are means of $(n=3), \pm S D$. Mean are significant at $(p<0.05)$. Enzyme activity was carried out at $\mathrm{pH} 7$ and $50^{\circ} \mathrm{C}$.

\section{Effect of single and agro-waste cocktail on CMCase and FPase production.}

In order to establish the degradation capacity of the isolates, the co-culture was grown on different agro-waste biomass singly and as combinations. The CMCase and FPase production by the co-cultures on the agro-waste biomass (single and cocktail) is presented in Fig. 5. The RB produced higher cellulases than the other agro-waste biomass tested. The maximum CMCase and FPase activity recorded on RB were 3.15 and 0.67 $\mathrm{U} / \mathrm{mL}$, respectively. A similar amount of CMCase $(0.54 \mathrm{U} / \mathrm{mL})$ with little difference in FPase production was observed on $\mathrm{CD}$ and $\mathrm{RS}+\mathrm{CD}$ (maximum activity 0.13 and 0.17 $\mathrm{U} / \mathrm{mL}$, respectively). The CMCase and FPase activity recorded on RS were 0.40 and 0.21 $\mathrm{U} / \mathrm{mL}$, respectively, while on $\mathrm{RB}+\mathrm{RS}$ was 0.33 and $0.24 \mathrm{U} / \mathrm{mL}$, respectively. However, the maximum CMCase and FPase activity on $\mathrm{RB}+\mathrm{CD}(0.26$ and $0.17 \mathrm{U} / \mathrm{mL})$ and $\mathrm{RB}+\mathrm{RS}+\mathrm{CD}$ $(0.29$ and $0.18 \mathrm{U} / \mathrm{mL})$ were the lowest among the agro-waste carbon source investigated. Based on the maximum enzyme activities on each agro-waste tested, it was observed that RB supported CMCase and FPase production (5.8 and 3.9-times), (7.8 and 3.2-times) and (10.8 and 3.7-times) better than $\mathrm{RS}+\mathrm{CD}, \mathrm{RS}$, and $\mathrm{RB}+\mathrm{RS}+\mathrm{CD}$, respectively. While the addition of RS to CD improved the activity of the enzymes over RS only, the other cocktail agro-waste carbon source tested was not able to encourage improvement in the enzymes when compared with enzyme production on their single substrate.

There are many factors that could be responsible for these results. One of the factors could be attributed to the difference in lignocellulosic composition of each agro-waste biomass. For example, rice bran in addition to cellulose, hemicellulose, and lignin, contain bran oil 24\%, and protein 18\%. Moreover, it also rich in vitamins B, E, and other essential minerals (Randall et al. 1985). These constituents could provide additional nutritional requirement for the co-cultures, by improving growth performance and likewise enzyme 
production. Such observations (higher cellulase production on rice bran) have been reported with respect to Bacillus subtilis A8, which produced highest cellulase activity on rice bran than on corn cobs (Soeka and Sulistiani 2019). Similarly, rice bran has also been implicated in improving cellulase production by Aspergillus flavus (Utharalakshmi et al. 2014) and Fusarium oxysporum (Basak and Rangan 2018). Similar to this study, Bacillus thuringiensis grown on Prosopis africana pod (PAP) mixed with corn cobs improved endoglucanase production $(0.111 \mathrm{U} / \mathrm{mL})$ over single corn cobs $(0.099 \mathrm{U} / \mathrm{mL})$ but lower than PAP single substrate $(0.138 \mathrm{U} / \mathrm{mL})$ (Oni et al. 2020). It is well known that agro-waste biomass consist of complex cellulose and hemicellulose polymer, encrusted by the highly polymerized lignin that leads to difficulties in conversion process (Baruah et al. 2018). Hence, pretreatment is required to improve the digestibility and accessibility of the cellulose matrix through the removal of lignin. Nevertheless, Bacillus pumilus EB3 produced a lower endoglucanase activity $(0.063 \mathrm{U} / \mathrm{mL})$ under optimized conditions on oil palm empty fruit bunch (OPEFB) (Ariffin et al. 2008). Likewise, CMCase (0.21 U/mL) and FPase $(0.13 \mathrm{U} / \mathrm{mL})$ activity was recorded by thermophilic Bacillus subtilis BHUJPVH12 grown on CMC and filter paper substrate (Singh et al. 2019). In another study, a lower CMCase activity $0.108 \mathrm{U} / \mathrm{mL}$ from B. aureus was observed on MCC (Oke et al. 2016). In the current study, better results were found in terms of the enzyme activities.

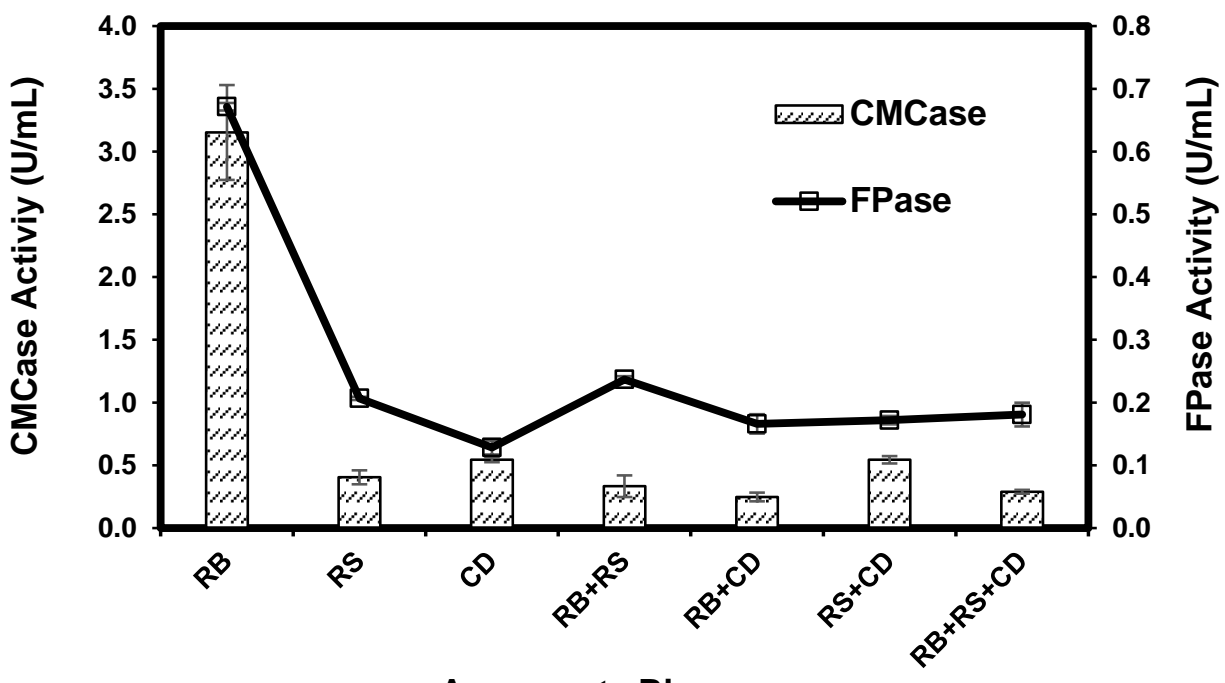

Agro-waste Biomass

Fig. 5. Effect of single and agro-waste cocktails on CMCase and FPase activity from co-culture of $B$. licheniformis and B. paralicheniformis. Enzyme activity was carried out at $\mathrm{pH} 7$ and $50^{\circ} \mathrm{C}$. Values are means of $(n=3), \pm S D$. Mean are significant at $(p<0.05)$.

\section{Effect of temperature on CMCase and FPase production by the co-culture}

The co-culture showed an increase in CMCase and FPase activities with increase in temperature, with the highest value (CMCase: $50 \mathrm{U} / \mathrm{mL}$, FPase: $8.9 \mathrm{U} / \mathrm{mL}$ ) at $45^{\circ} \mathrm{C}$, followed by a decline in the enzyme activities with further increase in temperature (Fig. 6). The activity of CMCase was totally inhibited at $55^{\circ} \mathrm{C}$, although FPase still retained some of its activities even at $60{ }^{\circ} \mathrm{C}$. A decrease in activities at higher temperatures could be attributed to the denaturation of enzymes at higher temperature. Temperature could also affect the secretion of enzymes as a result of modification in the physical properties of the cell membrane of the producing organism. Several Bacillus species have been reported to 
produce cellulase optimally at varying temperatures. Currently, there are few studies on cellulase production from co-cultures of bacterial species, and even the reported ones did not optimize the cellulase production. Hence, the current results could not be adequately compared with previous studies on co-cultures. Similar to the authors' findings, Shakoor et al. (2013) reported the highest temperature cellulase production by Bacillus megaterium $\mathrm{S} 3$ at $45^{\circ} \mathrm{C}$. Likewise, optimal cellulase production by Bacillus licheniformis NCIM 5556 isolated from hot spring was observed at $43.4{ }^{\circ} \mathrm{C}$. (Shajahan et al. 2017). In contrast to the current findings, Islam et al. (2019) detected temperature at $35{ }^{\circ} \mathrm{C}$ most suitable for enhanced cellulase production by Bacillus sp. For Paenibacillus sp. and Bacillus subtilis MU S1, optimal cellulase production was observed at $40{ }^{\circ} \mathrm{C}$ (Sreena and Sebastian 2018; Islam and Roy 2019).

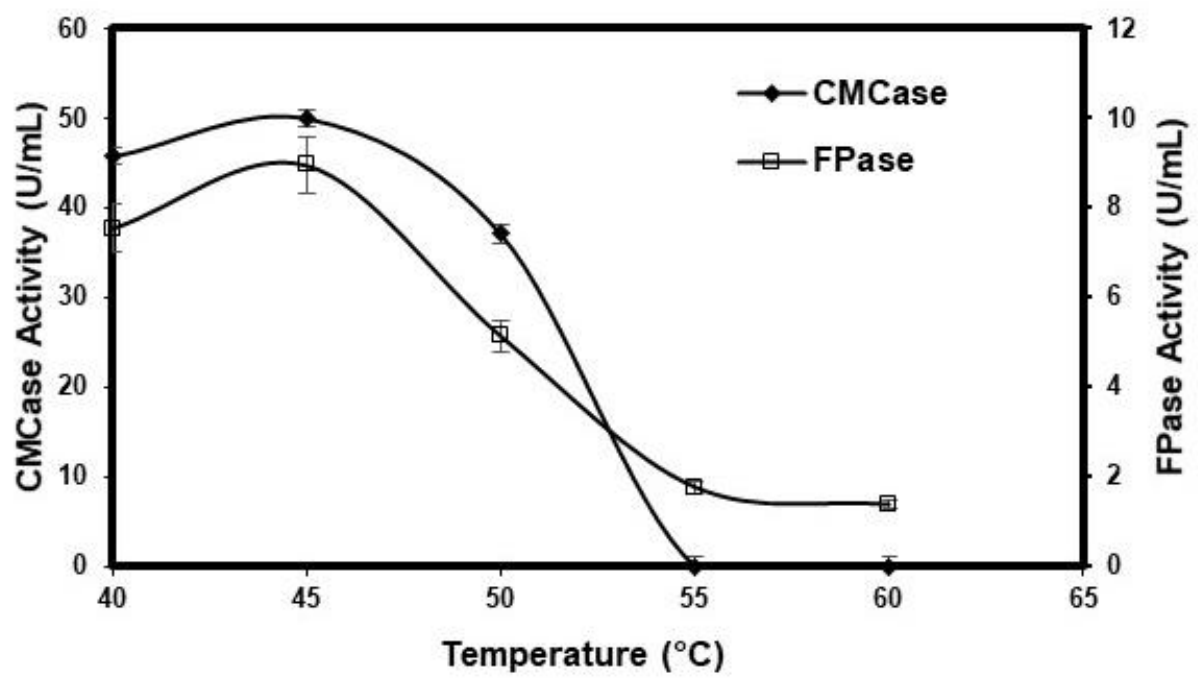

Fig. 6. Effect of temperature on CMCase and FPase activity from co-culture of $B$. licheniformis and $B$. paralicheniformis on rice bran medium. Enzyme activity was carried out at $\mathrm{pH} 7$ and $50{ }^{\circ} \mathrm{C}$. Values are means of $(n=3), \pm S D$. Mean are significant at $(p<0.05)$.

Effect of pH on CMCase and FPase production by the co-culture

The CMCase and FPase activity production by the co-culture showed an increase in activity as the $\mathrm{pH}$ increased and attained optimum activity at $\mathrm{pH}$ 7. Beyond $\mathrm{pH} 7.0$, the activity decreased until $\mathrm{pH}$ 8.0. At $\mathrm{pH} 7.0$ the optimum activity of CMCase and FPase were 51.1 and $8.9 \mathrm{U} / \mathrm{mL}$, respectively. The enzyme activities were reduced at $\mathrm{pH}$ lower than and beyond 7.0. For instance, the CMCase activity and FPase activity were reduced to 16.5 and $5.40 \mathrm{U} / \mathrm{mL}$ at $\mathrm{pH} 4.0$, while $29.4 \mathrm{U} / \mathrm{mL}$ (CMCase) and $7.2 \mathrm{U} / \mathrm{mL}$ (FPase) activity were attained at $\mathrm{pH}$ 8.0. It was clearly evident from various researchers' reports that media at pH 7.0 shows significant effect on cellulase production (Shajahan et al. 2017; Sreena and Sebastian 2018). Previous studies reported that maximum CMCase from Bacillus subtilis K-18 was attained at pH 5.0 (Irfan et al. 2017). Soeka and Sulistiani (2019), obtained maximum yield of CMCase from Bacillus subtilis A8 grown on rice bran at $\mathrm{pH}$ 7, while the same isolate grown on corn cobs exhibited maximum CMCase activity at $\mathrm{pH}$ 7.0. A strain of Paenibacillus sp. isolated from molasses exhibited maximum CMCase activity at initial $\mathrm{pH}$ medium of 7.0 in submerge fermentation (Islam and Roy 2019). An initial medium $\mathrm{pH}$ of 7.0 has been reported for maximum CMCase production by Bacillus licheniformis TLW-3 in submerge fermentation (Kiran et al. 2018). The acidity or alkalinity $(\mathrm{pH})$ of the media influences the growth of microorganisms, hence different bacteria present varying optimal $\mathrm{pH}$ for cellulase production. 


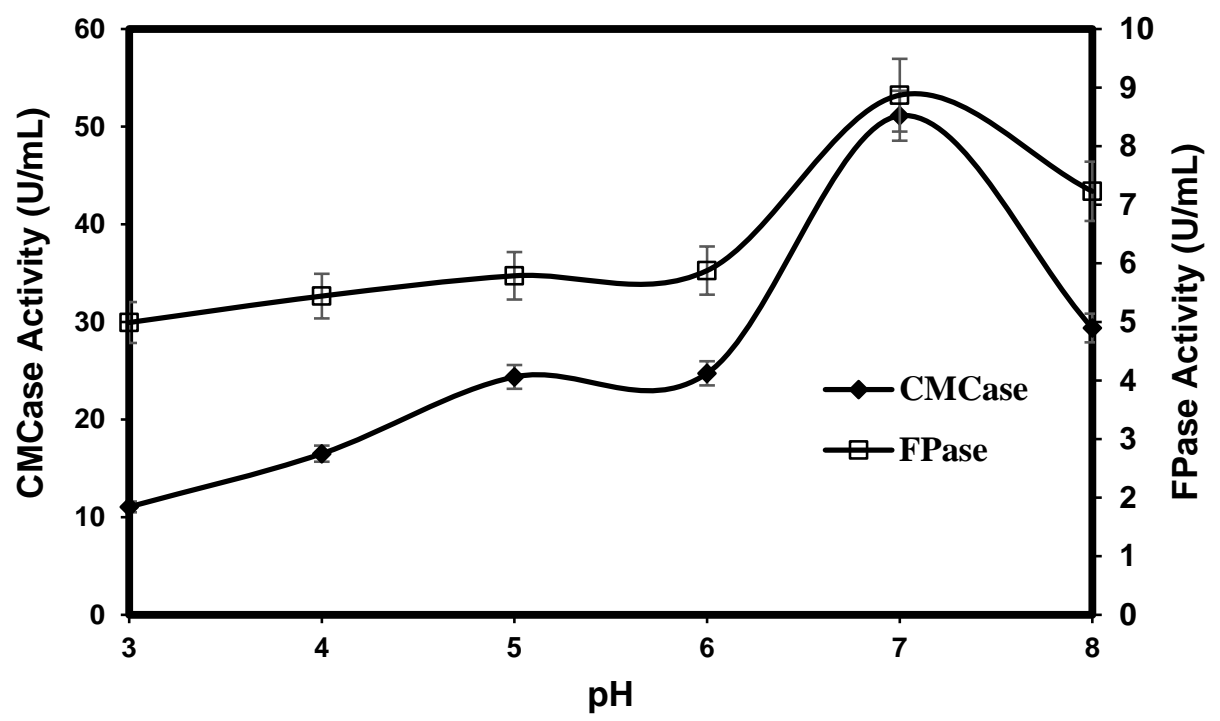

Fig. 7. Effect of $\mathrm{pH}$ on CMCase and FPase activity from co-culture of $B$. licheniformis and $B$. paralicheniformis on rice bran medium. Enzyme activity was carried out at $\mathrm{pH} 7$ and $50^{\circ} \mathrm{C}$. Values are means of $(n=3), \pm S D$. Mean are significant at $(p<0.05)$.

Effect of chicken-manure supplementation on CMCase and FPase activity by the co-culture

The effect of nitrogen sources on CMCase and FPase activity was examined on different concentrations of chicken manure, using peptone and ammonium sulphate as control. The increase or decrease in enzyme production shows varying response to the chicken manure concentrations. The CMCase and FPase activity increased as the chicken manure concentration increased and attained optimum activity at CM2, which later decreased at concentrations CM3 to CM5. The optimum concentration of chicken manure at CM2 increased the CMCase and FPase activity to 79.8 and $12.8 \mathrm{U} / \mathrm{mL}$, respectively. It is noteworthy that supplementation of the basal medium with different concentrations of the chicken manure produced even higher cellulase activity than the peptone (organic nitrogen) and ammonium sulphate (inorganic nitrogen) supplementation. For instance, the least CMCase $(69.9 \mathrm{U} / \mathrm{mL})$ and FPase $(10.2 \mathrm{U} / \mathrm{mL})$ activity obtained from chicken manure supplementation at $\mathrm{CM} 3$ produced higher enzyme activity than that with peptone supplementation (CMCase: $29.6 \mathrm{U} / \mathrm{mL}$; FPase: $10.3 \mathrm{U} / \mathrm{mL}$ ) and ammonium sulphate (CMCase: $50.7 \mathrm{U} / \mathrm{mL}$; FPase: $8.7 \mathrm{U} / \mathrm{mL}$ ). The improvement in cellulase production in fermentation supplemented with the chicken manure could be attributed to the presence of growth activators in addition to organic nitrogen naturally present. The growth activators might stimulate fast growth and higher enzyme production. Nitrogen rich sources, such as chicken manure, in the right concentration could serve as a complete nutrient pool for the production of enzymes in bioprocess fermentation. Nitrogen supplementation of oil palm empty fruit bunch with lignocellulose-rich nitrogen source, such as cyanobacteria, enhanced the production of the three cellulase components (CMCase, FPase, and $\beta$ glucosidase) by Aspergillus terreus. Nitrogen supplementation with soy bean meal improved cellulase and xylanase production on saw dust lignocellulose (Pedri et al. 2015). Thomas et al. (2018) reported that among all organic nitrogen sources tested, only corn steep solids could enhance cellulase production by Bacillus sp. SV1. The corn steep solids contain amino acids, vitamins, and minerals and was found to improve cellulase production from Streptomyces drozdowiczii (de Lima et al. 2005) and Streptomyces malaysiense (Nascimento et al. 2009). Substantial amounts of CMCase and FPase could be produced 
from the co-culture of B. licheniformis and B. paralicheniformis grown on rice bran and chicken manure, an inexpensive carbon and nitrogen source in a simple shake flask batch fermentation. The cellulase titre achieved by the co-culture could be further improved by using other modes of fermentation such as fed-batch and continuous fermentation or batch bioreactor fermentation. Further optimization techniques, such as response surface methodology or factorial design, could be necessary for further improvement in cellulase production. Furthermore, additional cellulase inducers may be applied to improve cellulase production.

This represents the first report on the potential application of chicken manure as nitrogen supplement for the production of cellulase by co-culture of $B$. licheniformis and $B$. paralicheniformis. A large amount of chicken manure is generated as waste from numerous poultry houses. The use of such poultry waste does not only reduce the cost of raw material for cellulase production but also improved cellulase production. Further research along the area of this study will open the ways for new efforts to utilize co-culture in combination with this essential organic nitrogen as an eco-friendly and cost-effective tool in fermentation technology to increase the production of industrially essential bacteria enzymes.

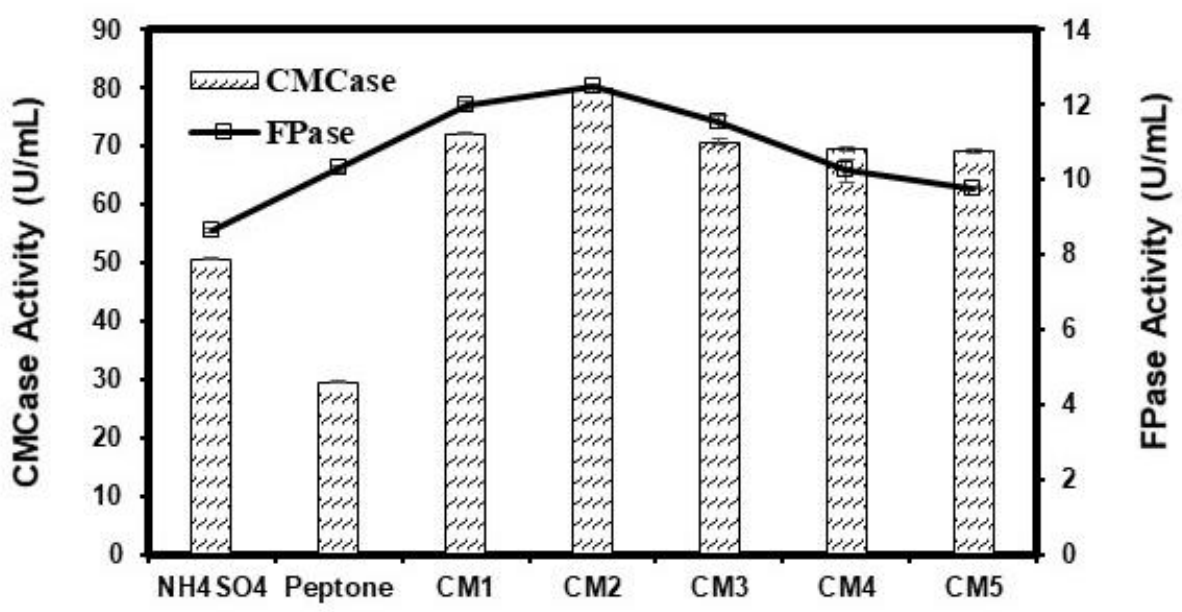

Nitrogen Sources

Fig. 8. Effect of nitrogen sources on CMCase and FPase activity from co-culture of $B$. licheniformis and $B$. paralicheniformis grown on rice bran medium. Enzyme activity was carried out at $\mathrm{pH} 7$ and $50^{\circ} \mathrm{C}$. Values are means of $(n=3), \pm S D$. Mean are significant at $(p<0.05)$.

\section{CONCLUSIONS}

1. Two cellulolytic bacteria isolated from compost were identified as B. licheniformis 2B40 and B. paralicheniformis 20B40 based on 16S rDNA gene sequence homology.

2. The efficacy of cellulase was greatly enhanced in fermentation using the co-culture compared to the use of the monoculture. Culture condition at $45^{\circ} \mathrm{C}, \mathrm{pH} 7$ in medium containing $1 \%(\mathrm{w} / \mathrm{v})$ rice bran enhanced further cellulase production. Furthermore, cellulase was greatly improved in fermentation media containing $2 \%$ chicken manure compared to other commercial nitrogen sources such as peptone and ammonium sulphate. 
3. At all the above conditions, the final activity of CMCase and FPase was 79.8 and 12.8 $\mathrm{U} / \mathrm{mL}$, respectively, which amounted to 257.4- and 59.5-fold increases, respectively, compared to monoculture of B. licheniformis $2 \mathrm{~B} 40$ and 306.9- and 83.3-fold increases against $B$. paralicheniformis 20B40 monoculture.

\section{REFERENCES CITED}

Afzal, M., Qureshi, M. Z., Khan, S., Khan, M. I., Ikram, H., Ashraf, A., Iqbal, A., and Qureshi, N. A., (2019). "Production, purification and optimization of cellulase by Bacillus licheniformis HI-08 isolated from the hindgut of wood-feeding termite," Int. J. Agric. Biol. 21(1), 125-134. DOI: 10.17957/IJAB/15.0872

Amore, A., Pepe, O., Ventorino, V., Birolo, L., Giangrande, C., and Faraco, V. (2013). "Industrial waste based compost as a source of novel cellulolytic strains and enzymes," FEMS Microbiol. Lett. 339(2), 93-101. DOI: 10.1111/1574-6968.12057

Ariffin, H., Hassan, M. A., Shah, U. K. M., Abdullah, N., Ghazali, F. M., and Shirai, Y. (2008). "Production of bacterial endoglucanase from pretreated oil palm empty fruit bunch by Bacillus pumilus EB3," J. Biosci. Bioeng. 106(3), 231-236. DOI: 10.1263/jbb.106.231

Balachandar, G., Khanna, N., and Das, D. (2013). "Biohydrogen production from organic wastes by dark fermentation," in: Biohydrogen, A. Pandey, J. S. Chang, P. C. Hallenbecka, and C. Larroche (eds.), Elsevier, Amsterdam, Netherlands, pp. 103-144. DOI: 10.1016/B978-0-444-59555-3.00006-4

Baruah, J., Nath, B. K., Sharma, R., Kumar, S., Deka, R. C., Baruah, D. C., and Kalita, E. (2018). "Recent trends in the pretreatment of lignocellulosic biomass for value-added products," Front. Energy Res. 6(141), 1-19. DOI: 10.3389/fenrg.2018.00141

Basak, S., and Rangan, L. (2018). "Production, characterization and inhibition of fungal cellulases utilizing rice bran as substrate in solid state fermentation," Microbiol. Curr. Res. 2(3), 69-74. DOI: 10.35841/2591-8036.18-821

Bhattacharya, A., and Pletschke, B. I. (2014). "Thermophilic Bacilli and their enzymes in composting," in: Composting for Sustainable Agriculture, D. K. Maheshwari (ed.), Springer, Cham, Switzerland, pp. 103-124. DOI: 10.1007/978-3-319-08004-8_6

Dabhi, B., Vyas, R., and Shelat, H. (2014). "Use of banana waste for the production of cellulolytic enzymes under solid substrate fermentation using bacterial consortium," Int. J. Curr. Microbiol. App. Sci 3(1), 337-346.

de Lima, A. L. G., do Nascimento, R. P., da Silva Bon, E. P., and Coelho, R. R. R. (2005). "Streptomyces drozdowiczii cellulase production using agro-industrial byproducts and its potential use in the detergent and textile industries," Enzyme Microb. Technol. 37(2), 272-277. DOI: 10.1016/j.enzmictec.2005.03.016

Gupta, M., Sharma, M., Singh, S., Gupta, P., and Bajaj, B. K. (2015). "Enhanced production of cellulase from Bacillus licheniformis K-3 with potential for saccharification of rice straw," Energy Technol. 3(3), 216-224. DOI: 10.1002/ente.201402137

Hwang, H. Y., Kim, S. H., Kim, M. S., Park, S. J., and Lee, C. H. (2020). "Cocomposting of chicken manure with organic wastes: Characterization of gases emissions and compost quality," Appl. Biol. Chem. 63, 3. DOI: 10.1186/s13765-0190483-8 
Irfan, M., Mushtaq, Q., Tabssum, F., Shakir, H. A., and Qazi, J. I. (2017).

"Carboxymethyl cellulase production optimization from newly isolated thermophilic

Bacillus subtilis K-18 for saccharification using response surface methodology," AMB Express 7(1), article no. 29. DOI: 10.1186/s13568-017-0331-3

Islam, F., and Roy, N. (2019). "Isolation and characterization of cellulase-producing bacteria from sugar industry waste," American J. BioSci. 7(1), 16-24. DOI: 10.11648/j.ajbio.20190701.13

Islam, M., Sarkar, P. K., Mohiuddin, A., and Suzauddula, M. (2019). "Optimization of fermentation condition for cellulase enzyme production from Bacillus sp.," Malaysian J. Halal Res. 2(2) 19-24. DOI: 10.2478/mjhr-2019-0009

Karanja, A. W., Njeru, E. M., and Maingi, J. M. (2019). "Assessment of physicochemical changes during composting rice straw with chicken and donkey manure," Int. J. Recyl. Org. Waste Agric. 8(1), 65-72. DOI: 10.1007/s40093-019-0270-x

Karuppiah, V., Zhixiang, L., Liu, H., Vallikkannu, M., and Chen, J. (2021). "Co-culture of Vell-overexpressed Trichoderma asperellum and Bacillus amyloliquefaciens: An eco-friendly strategy to hydrolyze the lignocellulose biomass in soil to enrich the soil fertility, plant growth and disease resistance," Microb. Cell Fact. 20, 57. DOI:10.1186/s12934-021-01540-3

Kato, S., Haruta, S., Cui, Z. J., Ishii, M., and Igarashi, Y. (2005). "Stable coexistence of five bacterial strains as a cellulose-degrading community," Appl. Environ. Microbiol. 71(11), 7099-7106. DOI: 10.1128/AEM.71.11.7099-7106.2005

Kazeem, M. O., Shah, U. K. M., and Baharuddin, A. S. (2016). "Enhanced cellulase production by a novel thermophilic Bacillus licheniformis 2D55: Characterization and application in lignocellulosic saccharification," BioResources 11(2), 5404-5423. DOI: 10/15376/biore.11.2.5404-5423

Kazeem, M. O., Shah, U. K. M., Baharuddin, A. S., and AbdulRahman, N. A. (2017). "Prospecting agro-waste cocktail: Supplementation for cellulase production by a newly isolated thermophilic B. licheniformis 2D55," Appl. Biochem. Biotechnol. 182(4), 1318-1340 DOI: 10.1007/s12010-017-2401-z

Kinet, R., Destain, J., Hiligsmann, S., Thonart, P., Delhalle, L., Taminiau, B., Daube, G., and Delvigne, F. (2015). "Thermophilic and cellulolytic consortium isolated from composting plants improves anaerobic digestion of cellulosic biomass: Toward a microbial resource management approach," Biores. Technol. 189, 138-144. DOI: 10.1016/j.biortech.2015.04.010

King, W., and Hurst, A. (1963). "A note on the survival of some bacteria in different diluents," J. Appl. Bacteriol. 26(3), 504-506. DOI: 10.1111/j.13652672.1963.tb04803.x

Kiran, T., Asad, W., Ajaz, M., Hanif, M., and Rasool, S. A. (2018). "Industrially relevant cellulase production by indigenous thermophilic Bacillus licheniformis TLW-3 strain: Isolation-molecular identification and enzyme yield optimization," Pakistan J. Pharma. Sci. 31(6) 2333-2340.

Kuvvet, C., Uzuner, S., and Cekmecelioglu, D. (2019). "Improvement of pectinase production by co-culture of Bacillus spp. using apple pomace as a carbon source," Waste Biomass Valor. 10(5), 1241-1249. DOI: 10.1007/s12649-017-0142-4

Liang, Y. L., Zhang, Z., Wu, M., Wu, Y., and Feng, J. X. (2014). "Isolation, screening, and identification of cellulolytic bacteria from natural reserves in the subtropical region of China and optimization of cellulase production by Paenibacillus terrae ME27-1," BioMed Res. Int. 1-13. DOI: 10.1155/2014/512497 
Miller, G. L. (1959). "Use of dinitrosalicylic acid reagent for determination of reducing sugar," Anal. Chem. 31(3), 426-428. DOI: 10.1012/ac60147a030

Nascimento, R. P., Junior, N. A., Pereira, N., Jr., Bon, E. P., and Coelho, R. R. (2009). "Brewer's spent grain and corn steep liquor as substrates for cellulolytic enzymes production by Streptomyces malaysiensis," Lett. Appl. Microbiol. 48(5), 529-535. DOI: 10.1111/j.1472-765X.2009.02575.X

Oke, M. A., Annuar, M. S. M., and Simarani, K. (2016). "Enhanced endoglucanase production by Bacillus aerius on mixed lignocellulosic substrates," BioResources 11(3), 5854-5869. DOI: 10.15376/biores.11.3.5854-5869

Onwudike, S.U. (2010). "Effectiveness of cow dung and mineral fertilizer on soil properties, nutrient uptake and yield of sweet potato (Ipomoea batatas) in Southeastern Nigeria". Asian J. Agric. Res, 4(3).148-154.

DOI: 10.3923/ajar.2010.148.154

Oni, O. D., Oke, M. A. and Sani, A. (2020). "Mixing of Prosopis africana pods and corn cob exerts contrasting effects on the production and quality of Bacillus thuringiensis crude endoglucanase," Prep. Biochem. Biotechnol 50(7), 735-744. DOI: $10.1080 / 10826068.2020 .1734939$

Park, J. I., Steen, E. J., Burd, H., Evans, S. S., Redding-Johnson, A. M., Batth, T., Benke, P. I., D'haeseleer, P., Sun, N., Sale, K. L., et al. (2012). "A thermophilic ionic liquidtolerant cellulase cocktail for the production of cellulosic biofuels," PLOS One 7(5), 1-10. DOI: 10.1371/journal.pone.0037010

Pedri, Z., Lozano, L., Hermann, K., Helm, C., Peralta, R., and Tavares, L. (2015). "Influence of nitrogen sources on the enzymatic activity and grown by Lentinula edodes in biomass Eucalyptus benthamii," Braz. J. Biol. 75(4), 940-947 DOI: 10.1590/1519-6984.03214

Rahnama, N., Mamat, S., Shah, U. K. M., Ling, F. H., Rahman, N. A. A., and Ariff, A. B. (2013). "Effect of alkali pretreatment of rice straw on cellulase and xylanase production by local Trichoderma harzianum SNRS3 under solid state fermentation," BioResources 8(2), 2881-2896. DOI: 10.15376/biores.8.2.2881-2896

Randall, J., Sayre, R., Schultz, W., Fong, R., Mossman, A. P., Tribelhorn, R., and Saunders, R. M. (1985). "Rice bran stabilization by extrusion cooking for extraction of edible oil," J. Food Sc. 50(2), 361-364. DOI: 10.1111/j.1365-2621.1985.tb13402.x

Ransom-Jones, E., McCarthy, A. J., Haldenby, S., Doonan, J., and McDonald, J. E. (2017). "Lignocellulose-degrading microbial communities in landfill sites represent a repository of unexplored biomass-degrading diversity," Msphere 2(4), 1-13. DOI: 10.1128/mSphere.00300-17

Rastogi, G., Bhalla, A., Adhikari, A., Bischoff, K. M., Hughes, S. R., Christopher, L. P., and Sani, R. K. (2010). "Characterization of thermostable cellulases produced by Bacillus and Geobacillus strains," Bioresource Technol. 101(22), 8798-8806. DOI: 10.1016/j.biortech.2010.06.001

Rastogi, G., Muppidi, G. L., Gurram, R. N., Adhikari, A., Bischoff, K. M., Hughes, S. R., Apel, W. A., Bang, S. S., Dixon, D. J., and Sani, R. K. (2009). "Isolation and characterization of cellulose-degrading bacteria from the deep subsurface of the Homestake gold mine Lead, South Dakota, USA," J. Ind. Microbiol. Biotechnol. 36(4), 585-598. DOI: 10.1007/s10295-009-0528-9

Salim, A. A., Grbavčić, S., Šekuljica, N., Stefanović, A., Jakovetić Tanasković, S., Luković, N., and Knežević-Jugović, Z. (2017). "Production of enzymes by a newly isolated Bacillus sp. TMF-1 in solid state fermentation on agricultural by-products: 
The evaluation of substrate pretreatment methods," Bioresource Technol. 228, 193200. DOI: $10.1016 /$ j.biortech.2016.12.081

Samad, K. A., Zainol, N., Yussof, H. W., Khushairi, Z. A., Sharif, N. S. A. M., \& Syukri, N. S. M. (2020). "Isolation, identification and characterization of soil bacteria for the production of ferulic acid through co-culture fermentation using banana stem waste". SN Appl. Sci. 2, 339 (1-12). | DOI:10.1007/s42452-020-2151-3

Septiani, D., Suryadi, H., Mun'im, A., and Mangunwardoyo, W. (2019). "Production of cellulase from Aspergillus niger and Trichoderma reesei mixed culture in carboxymethylcellulose medium as sole carbon," J. Biol. Divers. 20(12), 3539-3644. DOI: $10.13057 /$ biodiv/d201211

Shajahan, S., Moorthy, I. G., Sivakumar, N., and Selvakumar, G. (2017). "Statistical modeling and optimization of cellulase production by Bacillus licheniformis NCIM 5556 isolated from the hot spring, Maharashtra, India," J. King Saud. Uni. Sci. 29(3), 302-310. DOI: 10.1016/j.jksus.2016.08.001

Shakoor, S., Aftab, S., and Rehman, A. (2013). "Characterization of cellulose degrading bacterium, Bacillus megaterium S3, isolated from indigenous environment," Pak. J. Zool. 45(6), 1655-1662.

Singh, S., Sivakumar, N., and Verma, J. P. (2019). "Developing thermophilic efficient cellulose degrading consortium for glucose production from different agro-residues," Front. Energy Res. 7, article no. 61. DOI: 10.3389/fenrg.2019.00061

Soeka, Y., and Sulistiani (2019). "Production and characterization of cellulase from the newly isolated Bacillus subtilis A8 on rice bran and corncob," in: IOP Conference Series: Earth and Environmental Science, Bogor, West Java, Indonesia, pp. 1-10. DOI: 10.1088/1755-1315/308/1/012033

Sreena, C., and Sebastian, D. (2018). "Augmented cellulase production by Bacillus subtilis strain MU S1 using different statistical experimental designs," J. Genet. Eng. Biotechnol. 16(1), 9-16. DOI: 10.1016/j.jgeb.2017.12.005

Sunphorka, S., Chavasiri, W., Oshima, Y., and Ngamprasertsith, S. (2012). "Protein and sugar extraction from rice bran and de-oiled rice bran using subcritical water in a semi-continuous reactor: optimization by response surface methodology," Int. J. Food Eng. 8(3) 1-22. DOI: 10.1515/1556-3758.2262

Tamura, K., Stecher, G., Peterson, D., Filipski, A., and Kumar, S. (2013). "Molecular evolutionary genetics analysis version 6.0," Mol. Biol. Evol. 30(12), 2725-2729. DOI: 10.1093/molbev/mst197

Thomas, L., Ram, H., and Singh, V. P. (2018). "Inducible cellulase production from an organic solvent tolerant Bacillus sp. SV1 and evolutionary divergence of endoglucanase in different species of the genus Bacillus," Braz. J. Microbiol. 49(2), 429-442. DOI: 10.1016/j.bjm.2017.05.010

Utharalakshmi, N., Kumar, A. G., and Narendrakumar, G. (2014). "Optimization of cellulase producing Aspergillus flavus SB4 by solid state fermentation using rice bran," J. Pure Appl. Microbiol. 8, 713-719.

Wood, T. M., and Bhat, K. M. (1988). "Methods for measuring cellulase activities," Methods Enzymol. 160, 87-112. DOI: 10.1016/0076-6879(88)60109-1

Yang, G., Yang, D., Wang, X., and Cao, W. (2021). "A novel thermostable cellulaseproducing Bacillus licheniformis A5 acts synergistically with Bacillus subtilis B2 to improve degradation of Chinese distillers' grains" Biores. Technol. 325. DOI: 10.1016/j.biortech.2021.124729 
Zhao, C., Deng, L., and Fang, H. (2018). "Mixed culture of recombinant Trichoderma reesei and Aspergillus niger for cellulase production to increase the cellulose degrading capability," Biomass Bioenerg. 112, 93-98. DOI: 10.1016/j.biombioe.2018.03.001

Zhou, K., Qiao, K., Edgar, S., and Stephanopoulos, G. (2015). "Distributing a metabolic pathway among a microbial consortium enhances production of natural products," Nat. Biotechnol. 33(4), 377-383. DOI: 10.1038/nbt.3095

Zulkifli, Z. B., Rasit, N. B., Umor, N. A., and Ismail, S. (2018). "The effect of $A$. fumigatus SK1 and Trichoderma sp. on the biogas production from cow manure," Mal. J. Fund. Appl. Sci. 14(3), 353-359.

Article submitted: February 22, 2021; Peer review completed: June 13, 2021; Revised version received: August 2, 2021; Accepted: August 22, 2021; Published: August 26, 2021.

DOI: $10.15376 /$ biores.16.4.6850-6869 